\title{
CHALLENGING PATRIARCHY: THE CHANGING DEFINITION OF WOMEN'S EMPOWERMENT
}

\author{
Bentul Mawa*
}

\begin{abstract}
Traditionally, prevailing patriarchal norms and social values have confined Bangladeshi women to the private sphere and placed them in a position of disempowerment vis-à-vis men. Since the 1970s the emergence of the readymade garment (RMG) industry has provided women with opportunities for waged work into the public sphere and linked them into the global economy. By using Naila Kabeer's conceptualisation of empowerment and Walby's theory of patriarchy as theoretical lenses of analysis, this paper examines what happens when women are empowered in the economic sphere and whether that transfers over into the domestic sphere in terms of changes in patriarchal relations. Evidence from semi-structured interviews with 40 female garment workers, the paper analyses their lives outside the workplace. It argues that experience of paid work can offer female RMG workers a degree of empowerment within home and society, but the level of this varied for women. For "Independent" and "Progressive" women the state of gender relations was changing to an extent as a result of paid employment, whereas "Traditional" women's entry into the workplace had not brought about any change in the private form of patriarchy. Overall, women's participation in paid employment such as their role as a wage earner, their increased freedom of movement and autonomy, self-confidence, a greater degree of awareness regarding their life decisions presents a radical challenge to the myth of the male breadwinner model of the family in Bangladesh and the notion of patriarchy.
\end{abstract}

Keywords: empowerment, patriarchy, gender relations, Readymade Garment (RMG)

\section{Introduction}

In the male-dominated patriarchal society of Bangladesh, men and women have traditionally been restricted to their own spheres of activity (Cain, Khanam, \&

\footnotetext{
* Bentul Mawa, PhD is Associate Professor of Personnel Management and Public Administration at Graduate Training Institute, Bangladesh Agricultural University. Email: b.mawa@ bau.edu.bd

Social Science Review [The Dhaka University Studies, Part-D], Vol. 37, No. 2, December 2020
} 
Nahar, 1979). Women were confined within the private sphere to perform all the reproductive tasks at household level, while men participated in the productive activities outside the home (Souplet-Wilson, 2014). As increasing numbers of women work in export factories due to financial necessity, the task of earning money has been added to their domestic responsibilities, forcing them to work a "double shift" (Pearson, 2004; Hossain, 2012, p. 57), combining paid productive work with unpaid reproductive housework.

Although women's integration into the workforce has been seen as a necessary precondition for their empowerment, the impact of women's paid employment on some key aspects of their lives, including their well-being, has always been a hotly contested issue. Since the early 1980s, a growing body of research has been conducted on women's employment in paid work, specifically in the exportoriented sector in developing countries, but most earlier studies based in developing countries focused solely on the workplace (Paul-Majumder \& Begum, 2000; Zaman, 2001; Ward, Rahman, Islam, Akhter, \& Kamal, 2004; Kabeer \& Mahmud, 2004a, 2004b; Wright, 2006; Hancock, 2006; Glick \& Roubaud, 2006). Some other studies also exist which looked at the impact of working in this sector on women's position within the home but less in number (Kibria, 1995; Kabeer, 1997; Unni \& Bali, 2002; Souplet-Wilson, 2014; Ansell, Tsoeu-Ntokoane, \& Hajdu, 2015). A number of authors has argued that policy makers have neglected the private sphere when analysing women's life experiences (Feldman, 2001; Pearson, 2007; Chant \& Brickell 2013). In addition, authors who have studied women's experiences of work by looking at the effect that paid employment has on women's domestic gender relations and domestic power within the family have reached different conclusions on these issues (Meyer, 2006; Ong, 1987; Safa, 1990; Kibria, 1995; Kabeer, 1997). For example, Kibria (1995) concluded that Bangladeshi women's ability to control their income does not necessarily mean that they have been emancipated from traditional roles or religious norms. Kabeer (1997, 2004), however, reported the positive impact of employment on Bangladeshi women, arguing that they have been given a greater voice in household decision making, shifting the balance of power within the family. In order to contribute to some of the debates in the existing literature, this study has examined whether women's experiences of paid labour impact the lives of women beyond the confines of the RMG factory floor in Bangladesh. 
This paper builds on Naila Kabeer's conceptualisation of empowerment as the expansion of choice (1999), and Walby's (1990) model of patriarchy to analyse the ways in which RMG sector has enabled women to re-negotiate their position within home and society and to challenge patriarchy. Therefore, the second section reviews literature on empowerment, patriarchy, gender power relations in Bangladeshi society. The section three discusses methodology and section four analyses women's experiences at the household and societal level. By using women's real-life experiences, this paper avoids analysing women in the RMG sector as one homogenous group. Rather it shows different nature of women's experiences and empowerment. Women were grouped into three different categories based on their responses regarding household support, financial autonomy, and decision-making powers: (i) Traditional, (ii) Progressive, and (iii) Independent. This paper argues that experience of paid work can offer female RMG workers a degree of empowerment within home and society, but the level of this varied for women. The RMG sector has enhanced "Independent" and "Progressive" women's ability to formulate choices and act upon those choices, which enables them to challenge the myth of the male breadwinner model of the family in Bangladesh and the notion of patriarchy.

\section{Defining the Concept: Empowerment and Patriarchy}

Firstly, through a literature review this section seeks to define female empowerment to show how Naila Kabeer's (1999) conceptualisation of empowerment as the expansion of choice and then Walby's (1990) model of patriarchy are the most appropriate theoretical frameworks to explain women's empowerment at home and society. Gender power relations in Bangladeshi society is also explained to understand women's position here.

Feminist scholars such as Gita Sen and Caren Grown (1987), Jo Rowlands (1997) and Naila Kabeer (1999) were precursors of defining the concept of empowerment for women in developing countries. Their publications led to the incorporation of female empowerment into various policy making arena in the international development sector, as state actors sought to adopt a more progressive approach to improving the lives of women in the South (SoupletWilson, 2014). Therefore, female empowerment became a central component in policy making with regards to gender, exemplified with UN Women's Conference in Beijing 1995, and its incorporation into the third Millennium 
Development Goal (Batliwala, 2007; Townsend, Alberti, Mercado, Rowlands, \& Zapata, 1999). Nonetheless, as female empowerment has been heavily incorporated into the international development agenda, there are a variety of views on what it actually entails.

Proponents of the orthodox neoliberal discourse (World Bank, 2012; Hussain, 2011) define empowerment as an end itself and depict women's empowerment in purely economic terms. For feminist scholars, for women to experience empowerment, it is not simply by entering the workforce and changing their condition, but about self-efficacy for women to be able to change their position within social structures (Souplet-Wilson, 2014). In this way, empowerment is built upon the construction of 'power to', 'power with', 'power from within' as well as 'power over'. For feminist scholars who have conceptualised empowerment (Rowlands, 1997; Townsend et al., 1999; Kabeer, 1999), 'power over' relates to controlling power, which may be responded to with compliance or resistance. 'Power to' is the productive or decision-making power, also referred to as "generative or productive power" which creates new possibilities and actions without domination. 'Power with' is collective power and 'power within' is personal power (Rowlands cited in Said-Allsopp, 2013, p.22). This allows one to view empowerment as a process as well as an end point, as these constructions of power show how people's states evolve over time. Moreover, this construction is useful as it shows that empowerment is multifaceted, showing that rather than simply increasing someone's income, it includes the economic, social, psychological, and physical wellbeing of people (Said-Allsopp, 2013).

The definition of empowerment given by Naila Kabeer is: "the expansion in people's ability to make strategic life choices in a context where this ability was previously denied to them" (cited in Malhotra, Schuler, \& Boender, 2002, p.6). Kabeer's (1999, 2010, pp.13-14) definition encompasses key terminology used in feminist literature. This conceptualisation defines power in terms of one's ability to make choices, and thus empowerment refers to the processes by which those who have been denied the ability to make choices acquire such ability. As those who exercise choice in their lives may be very powerful but are not empowered, as they were never disempowered in the first place. This definition is useful, as it does not assume that people are powerless (Oakley, 2001) but rather situates them within a process of change, illustrating a shift in power dynamics. When analysing choice, Kabeer (1999) creates two distinct categories: first order 
choices and second order choices. First order choices are strategic choices that affect women's lives. This includes choosing where to live; whether to marry and who to; whether to have children and if so, how many; rights over children; freedom of movement; and being able to decide one's friendship networks. First order choices help frame second order choices, which affect the quality of life, but are not choices that define life's parameters. In addition, Kabeer $(1999$, p.16) focuses on strategic life choices that foster a "transformatory significance", being choices with the potential for challenging and destabilising social inequalities. The advantages of differentiating between strategic life choices and second order choices allows this paper to focus on the kinds of choices that foster a "transformatory significance" in the lives of women.

In addition to adopting Naila Kabeer's (1999) conceptualisation of empowerment, Walby's (1990) theory of patriarchy has been used to examine women's oppression and subordination at home and society. Walby $(1990,1996 \mathrm{a})$ suggested that one of the key feminist concepts, i.e., the theory of patriarchy, is a useful tool for understanding changes in gender relations, especially in terms of women's increasing participation in the labour market. This is because she thinks that a theory of patriarchy: "is both structural enough to grasp the scale and interconnectedness of these changes on a macro level, while flexible enough to capture change and diversity (historical and cross-cultural variation in gender inequality)" (1996a, p.1). Feminists use the term patriarchy as a concept to explain patriarchal relations, and like all other concepts, it is an effective tool for analysis which helps to understand the realities of women's experience.

The word 'patriarchy' comes from the Greek meaning 'the rule of the father' and was used originally to describe the herding societies of the Old Testament, in which the authority of the father over family members was practically absolute (LeGates, 2001, pp.11-12). The concept of patriarchy has a long, complicated, and contested history which has been defined in several different ways among social scientists. Weber (1947) used it to refer to a system of government in which men ruled societies through their position as heads of households. It acquired its feminist meaning relatively recently when Kate Millett, in Sexual Politics (1970), used it to describe to male domination and the power relationships by which men dominate women.

Some feminist scholars analyse patriarchy based on male dominance, power, and control over women's labour (Millet, 1970; Delphy, 1984; Hartmann, 1979; 
Walby, 1990), while others emphasise ideological factors or sexual control of women (Brownmiller, 1976; Rich, 1980; MacKinnon, 1989). Delphy (1984, p. 95) sees patriarchy as a system of oppression with a material base in the 'domestic mode of production', meaning that women provide domestic services in the family, where childbearing occurs, and where certain goods are produced for use and exchange. Under patriarchal relations of production women perform these tasks for the benefit of their husbands. Hence housewives are the direct producers while husbands expropriating the labour of their wives. She further argues that marriage is the institution by which women's unpaid work is appropriated by their husbands. In her essay on the 'Unhappy Marriage of Marxism and Feminism', Hartmann (1979, p. 11) defines patriarchy as: A set of social relations between men, which have a material base, and which though hierarchical, establish or create interdependence, and solidarity among men that enable them to dominate women. She argues that the material base of patriarchy is men's control over women's labour power, a control that is maintained by denying women access to necessary economically productive resources and by restricting their sexuality.

Walby (1996b, p. 28) sees patriarchy from a multi-dimensional approach and views patriarchy as "systematically structured gender inequality." Walby $(1989$, p. 213; 1990 , p. 21) conceptualises the system of patriarchy as being composed of six interrelated structures which she identifies as: "patriarchal relations in household work, patriarchal relations in paid work, a patriarchal state, male violence, patriarchal relations in sexuality, and patriarchal relations in cultural institutions including religions, media, and education". The six identified are real, deep structures and necessary to capture the variation in gender relations. Walby (1989, 1990) argues that by analysing these structures the varied forms of women's oppression and patriarchal practices can be adequately grasped in the period and place under consideration. In different times and places some of the structures are more important than others. The elimination of any one does not lead to the demise of the system as a whole. Walby (1990, 1996a, 1996b) further posits that the interrelationships between these structures create different forms of patriarchy: private and public, noting that the above six structures are present in each type of patriarchy, but the relationship between them and their relative significance varies. Private patriarchy is based upon household production, with a male (either husband or father), exercising direct individual control over a female in the relatively private sphere of the home. In this context, a man is the direct oppressor and beneficiary of 
the subordination of a woman. In public patriarchy, women are not barred from the public arena, but are, nonetheless, subordinated within all spheres of social action. The expropriation of women is performed collectively rather than by individual patriarchs, and segregationary strategies are used to subordinate women within all spheres of social action. This paper adopts Walby's (1990) model of patriarchy to explain women's position at home and society, for example, how patriarchal control is maintained through the appropriation of women's labour within marriage and household relationships, or how culture which includes the different norms and values of expected behaviour for Bangladeshi women disadvantages female workers within the household, and society.

\section{Gender Power Relations in Bangladeshi Society}

Culturally, Bangladesh is a relatively homogeneous society, with 90 percent of the population being Muslim, the remainder Hindu, Christian, or Buddhist (Blanchet \& Kramer, 1987). Religion and religious ideas are part of a general cultural context and one which is manifest in practices, institutions, and organisations. In her article on theorising patriarchy, Chowdhury (2009) argues that patriarchy is maintained in the Bangladeshi family through the misinterpretation of religion, the patriarchal view of Islam being: Man is the breadwinner and woman is the servant of men. In her opinion, this misinterpretation of Islamic beliefs allows men to control and exploit women even though marriage in Islam should be based on mutual peace, love, and compassion, not just satisfying men's needs.

The institution of purdah (female seclusion) is also widely misinterpreted in the traditional Bangladeshi family system where it is linked to religious sensibilities to control women. Kibria (1995, p. 293) explains that "while the outward symbol of purdah is the veil or curtain, it functions as a system of social control that emphasises the separation of women from men and the seclusion of women from the world outside the home". Purdah produces a gendered segregation of spheres and division of labour in society with women confined to the domestic responsibilities within the home space with limited rights. Men, on the other hand, specialise in those economic activities carried out in public spaces, such as trading and other forms of marketplace work (Cain et al., 1979).

Bangladeshi society can be seen as a typical example of patriarchy. Dominant patriarchal ideology has established male superiority as the 'norm' or natural 
order of things. Men enjoy greater power and authority simply because they are male. Traditionally women's functions are to give birth, nurse and raise their children and manage the household chores, whilst they are relatively powerless in the public sphere (Schuler, Hashemi, Riley, \& Akhter cited in Sultana, 2010, p. 123). 'Ideal women' possess the qualities of obedience, endurance, selflessness, and motherliness. They maintain bodily purity by behaving and dressing in a particular way, traditional, docile, participating in rather than challenging nation's culture and traditions. Those who fall short of the 'ideal' are classed as 'abnormal', 'deviant', lacking 'appropriate behaviour', even 'perverted' (Azim, 2010; Ali, 2012). Chowdhury (2009) argues that women are considered to be passive dependents and property of their husbands in the Bangladeshi family system. Patriarchy is maintained through the non-recognition of unpaid work done by women at home and capital accumulation strengthens patriarchy through the use of dowry system. Women are increasingly seen as an economic burden due to the rise of the dowry-based marriage system, which is linked increasing poverty and landlessness. The decreasing asset base of many households means that women's labour in the household carries limited returns and this coupled with limited employment opportunities for women, means they are increasingly perceived as an economic burden within households. Increasing incidence of violence against women has also been linked to the phenomenon of dowry, with women being victimised and abused for bringing insufficient resources into the household upon marriage (Wilson-Smillie, Eggen, \& Shefali, 1990; Kramsjo \& Wood, 1992).

Following national independence in 1971, the traditional family system in Bangladesh faced the challenge of widespread poverty in the rural areas as landholdings become increasingly fragmented. Traditional familial and villagebased mutual aid networks, and extended family systems have declined under the pressures of extreme poverty, with subsistence becoming a largely individual matter (Feldman, 1992; Baden, Green, Goetz, \& Guhathakurta, 1994). According to Blanchet \& Kramer (1987), poverty has weakened the 'patriarchal family as a unit of production'. Against this backdrop, vast numbers of Bangladeshi women have been obliged to go outside the bounds of the traditional family system to gain a livelihood casting off their age-old inhibitions and prejudices by taking up paid employment in RMG factories (Chowdhury, 2009; Khosla, 2009). In this context, the new roles offered by the RMG industry to its female workers clash with traditional patriarchal ideology as well as the national stereotype of 'ideal' 
women. This paper thus examines the extent to which women's role as wage earner has challenged traditional ideas and gender relations through such dramatic shifts.

\section{Methodology}

This study used qualitative approach to collect data from 40 female workers working in four Bangladeshi RMG factories. Within four factories, one factory was chosen from Dhaka export processing zone (EPZ), situated at Savar and three other factories were chosen outside the EPZ from Mirpur, Dhaka. Data were collected during June to September 2013. Snowball sampling was used to find a sample from the female workers at the chosen factories. The rationale for choosing this sampling strategy was that it enabled contact with difficult-toaccess populations (Tracy, 2013).

It proved difficult to obtain a wholly representative sample since there are different categories of workers in RMG factories (helper, operator, folder man, iron man, cutting master, packing man, electrician, mechanic, and sample designer). Women are over-represented in the helper and operator job categories and very few females work in supervisory or other categories (Paul-Majumder \& Begum, 2000). For this reason, the researcher chose to interview 40 females working as helpers or operators and endeavoured to interview different women at different points in their life trajectories, namely unmarried, married, and married with children, separated, widowed, deserted to get multiple viewpoints. Interviewees provided their mobile phone numbers during factory visits and were later contacted about their preferred time/place for the interview. Most opted to be interviewed in the private space of home since this means they are outside management supervision and control (Absar, 2001).

Ages of female workers in the non-EPZ RMG factories ranged from 18 to 30 with 93\% falling into this grouping, whereas $100 \%$ of their female counterparts at the EPZ were aged 20 to 30 (see Table 1). The average age of non-EPZ and EPZ female workers was 24 years and 26 years, respectively. This difference in age profile is also reflected in their marital status, with the EPZ employing more married female workers (67\%) than the other three non-EPZ factories (54\%). The figures for the unmarried female workers in EPZ and non-EPZ factories were $25 \%$ and $32 \%$ respectively. A small proportion of women (8\% from EPZ and 14\% from non-EPZ) were widowed, separated, and deserted. In this study, the average 
years of schooling were different for women from the EPZ and those from the non-EPZ factories: 10 years versus 6 years respectively (see Table 1). At EPZ, the minimum educational requirements for entry level/or helper and quality controller was secondary school certificate (SSC), whereas non-EPZ workers did not need any specific educational qualifications, as they were only required to read and write Bengali and to recognise English numbers.

Table 1: Socio-Demographic Profile of Female RMG Workers Interviewed

\begin{tabular}{|c|c|c|}
\hline Socio-Demographic Factors & $\begin{array}{l}\text { EPZ Factory } \\
(\mathbf{N}=12)\end{array}$ & $\begin{array}{c}\text { Non-EPZ } \\
\text { Factories }(\mathrm{N}=\mathbf{2 8})\end{array}$ \\
\hline Age (Years) & (\%) (Number) & (\%) (Number) \\
\hline $17-19$ & $0.0(0)$ & $25.0(7)$ \\
\hline $20-25$ & $50.0(6)$ & $50.0(14)$ \\
\hline $26-30$ & $50.0(6)$ & $18.0(5)$ \\
\hline $31+$ & $0.0(0)$ & $7.0(2)$ \\
\hline Average age (in years) & 26 & 24 \\
\hline \multicolumn{3}{|l|}{ Educational Attainment $^{1}$} \\
\hline Illiterate & $0.0(0)$ & $16.0(4)$ \\
\hline Primary & $0.0(0)$ & $48.0(13)$ \\
\hline Junior Secondary & $37.0(5)$ & $20.0(6)$ \\
\hline Secondary School Certificate (SSC) & $36.0(4)$ & $12.0(3)$ \\
\hline $\begin{array}{l}\text { Higher Secondary Certificate (HSC) and } \\
\text { above }\end{array}$ & $27.0(3)$ & $4.0(2)$ \\
\hline Average Number of Years in education & 10.0 & 6.0 \\
\hline \multicolumn{3}{|l|}{ Marital Status } \\
\hline Unmarried & $25.0(3)$ & $32.0(9)$ \\
\hline Married (no children) & Nil & $32.0(9)$ \\
\hline Married (with children) & $67.0(8)$ & $22.0(6)$ \\
\hline Widowed/separated/deserted & $8.0(1)$ & $14.0(4)$ \\
\hline \multicolumn{3}{|l|}{ Migratory Status } \\
\hline From Dhaka city & $0.0(0)$ & $11.0(3)$ \\
\hline From rural districts of Dhaka & $25.0(3)$ & $36.0(10)$ \\
\hline From elsewhere in Bangladesh & $75.0(9)$ & $53.0(15)$ \\
\hline Total Percentage of Female Workers & 100.0 & 100.0 \\
\hline
\end{tabular}

(Note: EPZ sample was calculated into $100 \%$ and non-EPZ sample was calculated the same as EPZ sample into 100\%). 
Forty semi-structured interviews constituted a large amount of data. These data then were coded and analysed using Eisenhardt's (1989) theory building approach to examine the experiences of work of female workers outside the workplace in terms of dual-burden, household support, pay and control of money, their role in decision making, as well as their change in attitudes and lifestyles.

\section{Results and Discussion}

This section assesses how employment in the RMG sector has affected the lives of women at the household and societal level, by analysing four key factors: female RMG factory workers and the double burden, control over income and expenditure, decision making powers, and changes in attitudes and lifestyles. This paper argues that experience of paid work can offer female RMG workers a varied degree of empowerment within home and society.

\section{Female RMG Factory Workers and the Double Burden}

Due to the gendered division of labour, even if women work full-time, women still bear responsibility for childcare and domestic chores (Goetz, 1999). With few exceptions, female interviewees, regardless of marital status, confirmed they were responsible for all housework including food shopping, cooking, and cleaning. Interviewees typically spent between 12- and 18-hours doing housework during the working week, in addition to four- or five-hour's housework on their weekly day off. Elson (2014) argues that women work not only more hours than men but undertakes much longer hours of unpaid work in the reproductive economy.

Female interviewees were asked if they received help from husbands or other household members with housework to find out more about their attitudes towards gender roles in the domestic sphere. In terms of getting support on domestic labour, differences were observed amongst female interviewees that were based on marital status. The "Independent" women in this study (13 of the total of 40 interviewees comprising eight single, five deserted, separated, and widowed women) had to perform all domestic chores in the absence of any supporting household members living with them. New living arrangements did not liberate these "Independent" women from housework but meant they had relatively less pressure on themselves within the household as they had more control over their money and greater freedom of movement. 
For "Traditional" women (13 married and 4 unmarried women from a total of 40 interviewees) employment in the RMG industry has not impacted on their gender roles, as it simply meant a double burden with working married women receiving no support within the household from husbands. Despite being full-time workers, most of these "Traditional" married women, some with children, some without, were adamant that housework and childcare was their responsibility as women. The comment by Sadia is typical of the responses which this question elicited from "Traditional" women:

My husband does not do anything. What would he do? There is not that much housework. Why would he do housework? That is my work, my responsibility. I do not allow my husband to do any housework. Sometimes he helps by bringing water from the well or buying groceries from the shop. I had never let him cook. (Sadia, QC-23, Married, Non-EPZ Factory)

"Traditional" women's responses revealed that there is a clear dividing line between male and female roles within the domestic sphere (my tasks/my responsibility). "Traditional" married women tend to perform all the household activities themselves and offered various explanations for non-involvement by males. Like Sadia, some excused husbands on the grounds that "There's not that much housework". Others voiced the opinion, like Nahar, that men were incompetent: "They wouldn't be able to do it like a woman. They'd mess everything up". Bhopal (1997, p.106) notes that this division of gender roles is so deeply engrained in South Asian tradition that it is considered 'natural' behaviour, meaning that women accept the traditional roles assigned to them without question and internalise the long-established division of labour within the household. "Traditional" women may suppress their "economic selves" to restore "traditional order" at home, in which case empowerment in the private realm continues to be suppressed by cultural value systems. Also, the resistance on the part of husbands to undertake unpaid household activities is partly due to the fact that they are aiming to uphold the patriarchal order. In this regard, Kabeer (2014) notes that men are protecting the remaining vestiges of heterosexual masculinity identity, as if they share in domestic work when women take up breadwinning roles, it will lead one to question what is left to distinguish them from women. It does highlight that men are upholding the status quo in order to maintain their unequal power relationships within household. Thus, entry into garments work does not liberate "Traditional" women from patriarchal practices, since their 
assumed responsibility of the reproductive economy shows that they are unable to transform their gender roles.

On the other hand, "Progressive" women (10 out of total 40 female interviewees comprising 10 married women) spoke of their experiences of moving towards sharing domestic labour tasks with husbands and as a result a change is beginning to take place.

If I return home at $8.00 \mathrm{pm}$ from the factory, I can finish the cooking by $9.30 \mathrm{pm}$. When I return at $10.00 \mathrm{pm}$, my husband cooks the rice if he gets back earlier than me. My husband helps with household chores, for example, while I am cooking in the morning, he makes the bed, sweeps the floor, and helps me bring the plates and glasses from our room; sometimes he chops the vegetables for me. (Afroja, Operator, 25, Married, Non-EPZ Factory)

Unlike the comments of the "Traditional" married interviewees, the responses from "Progressive" women suggest that there are significant signs of change in both male and female attitudes towards household chores with husbands participating within the domestic sphere in housework and childcare due to their wives' work commitments. This is extremely significant in a context where domestic labour is regarded as a female activity. "Progressive" women had begun to challenge traditional attitudes concerning gender roles, possibly because their higher level of education (having completed either secondary or higher secondary level of schooling) which gave them the confidence to confront cultural norms and social values and re-negotiate their positions regarding household tasks. Sultana (2010) highlights the important role that education plays in reducing discrimination against women and making men's and women's roles more equal within the household, finding that women with higher levels of education are more liberal and tend to espouse non-traditional ideologies compared to illiterate or less educated women. It may also be significant that these "Progressive" women were earning more money than their partners ${ }^{2}$, suggesting that material power may also play a role in a woman's ability to re-negotiate domestic gender relations and can improve woman's bargaining position within family.

\section{Control over Income and Expenditure}

To assess the impact of women's work on the economic position of the household, interviewees were asked to what extent women considered themselves 
to be financially autonomous. The degree of financial autonomy which female interviewees exercised varied considerably. The "Traditional" female interviewees did not retain control over their income, instead surrendering it to the male head of the household, and their acceptance of this male financial authority was a reflection of patriarchal cultural tradition, as the following response attest.

When I get my wages, I give them to my husband. I give it to him willingly. Then he gives me money for daily expenses. I ask him if I want to buy a dress, shampoo, or hair oil. My husband has not got any extra expenses. He spends for our family. I could keep my money, but I do not want to make my husband unhappy. (Husneara, Operator, 42, Married with children, Non-EPZ Factory)

"Traditional" women, like Husneara receive or would ask their husbands for a small part of their earnings for daily expenses or specific purchases. At most, these women manage a small amount of their income to ensure daily maintenance of the family. In Bangladeshi society, women expect economic success and financial provision from husbands, while men expect their wives to perform familial and mothering roles in return (Rao, 2012). The socialisation process teaches women and men the concept of the male breadwinner, who will take overall responsibility for meeting all the household's material needs. As a result, Husneara and many other "Traditional" interviewees thought it entirely natural to dutifully turn over their income to their husbands, believing, moreover, that keeping their earnings for themselves would offend their husbands in front of other family members. "Traditional" women were surrendering their wages to their husbands, in turn perpetuating men's position as head of the family. It is not surprising that for "Traditional" female interviewees entry into waged work had not significantly increased their power within the family, because they still conformed to patriarchal family relations.

However, the "Independent" women, who were single, divorced, widowed, and separated RMG workers, had full financial autonomy. In the traditional Bangladeshi family system, unmarried women are under the authority of fathers, brothers, and other male kin who control all aspects of their lives, including finance (Kibria, 1995). In this study, the 12 unmarried female participants, eight of whom were living unaccompanied by family members, had more control over their income. However, most still remitted a portion of their wages to their families in the villages: 
I spend money as I wish, budgeting for what I want. If I do extra overtime, then I get tk. 9,000 as a monthly wage. I pay rent of tk. 3,000; I have one DPS in which I deposit tk. 2,000 every month. I remit tk.1,000 to 3,000 to my mother and younger brother who still live in the village. (Rita, Operator, 22, Unmarried, Non-EPZ Factory)

Like Rita, most unmarried interviewees unaccompanied by family members in the city had control over their wages and spent their wages as they wished as they were the only breadwinner for the family. They either had no male relative in the household in authority over them or the male head of the household was too old to keep track of their money. Therefore, they retained full control of their earnings. Fernandez-Kelly (1990) argues that the patriarchal family system is based on the social and economic protection of women by men, so the inability of male kin to adequately provide for the needs of all family members may shift the dynamics of power within the household. Earning an income from RMG work and being able to control that money has provided these women with power which is indeed a shift from traditional cultural patterns in Bangladesh. These women are self-reliant which allows them to exercise a greater control over their own lives.

Table 2: Women's Control over Wages and Expenditures

\begin{tabular}{|l|c|l|c|}
\hline \multicolumn{1}{|c|}{$\begin{array}{c}\text { Control over Income and } \\
\text { Expenditure by Category }\end{array}$} & $\begin{array}{c}\text { No. of } \\
\text { Interviewees }\end{array}$ & \multicolumn{1}{|c|}{ Marital Status } & Total* \\
\hline $\begin{array}{l}\text { "Traditional" women with no } \\
\text { financial autonomy }\end{array}$ & 17 & $\begin{array}{l}\text { Single living with } \\
\text { parents }\end{array}$ & 4 \\
\cline { 2 - 4 } & Married women & 13 \\
\hline $\begin{array}{l}\text { "Progressive" women with partial } \\
\text { financial autonomy }\end{array}$ & 10 & Married women & 10 \\
\hline \multirow{2}{*}{$\begin{array}{l}\text { "Independent" women with financial } \\
\text { autonomy }\end{array}$} & 13 & Single living alone & 8 \\
\cline { 3 - 4 } & & Widowed/Separated/ & 5 \\
\hline Total = & \multicolumn{2}{|l}{ Deserted } & 40 \\
\hline
\end{tabular}

( ${ }^{*}$ Total number of women interviewed: 12 single living alone or with parents and $\mathbf{2 8}$ Married/Widowed/Separated/Deserted)

There was also evidence of significant changes taking place in the attitudes of "Progressive" married women regarding controlling money. This group of "Progressive" women had seventy percent or more wage control over their own 
daily expenditure and kept their own wages with their husband's knowledge. They made decisions about how to spend their pay and challenged the traditional notion of patriarchy:

I am able to spend money on my son's education. My salary is about tk. 11,500. As I am earning money, I can spend it if I want. I feel this is right. When my son wants money, I can give him some. Sometimes he wants new clothes from me. I can give them to him as I do not need to explain to anyone why I need to buy something. As both my husband and I are working, we use one salary for food, rent, and other expenditure whilst the other goes into the bank. (Asha, Operator, 20, Married with children, EPZ Factory)

Like Asha, the "Progressive" women indicated that they spent money themselves when required. Earning an income increases their personal purchasing power, representing a certain measure of socio-economic independence. Their wages formed a significant part of the family budget, but they also had at least one family member employed in the RMG sector or in a low-level managerial job. They considered themselves good wives and mothers and those with children considered they were working to give them a better life and education. For these women, employment was aimed totally towards the betterment of their households in the form of paying for a son's education or saving money for future family expenses.

I feel very fortunate and self-confident because I have my own income. I have set up a DPS account for my elder son to cover his future educational expenses. I deposit tk. 500 each month. Before I did not understand that I needed to save money; what I had saved I gave to my husband and relatives. I did not think of myself, but I now understand that I need to save for myself. If I do not have money, then I do not have any power. I do not have any value to anyone. (Farzana, Operator, 30, Married with children, EPZ Factory)

Women's financial autonomy is reflected in the above comment since these "Progressive" women prefer to keep their own wages for their own purchases. These women keep their own money in case of future uncertainties, aware that it gives them power, value, and a better bargaining position. Also, their experiences within the public sphere and continuous interaction with other people due to factory work has given them confidence suggesting the knock-on effect of this confidence on their relationship with husband. These "Progressive" women are taking a bold step in empowering themselves, going against the cultural expectation requiring subordination to their husbands. Thus, it can be argued that 
RMG work has given women the 'power to' challenge patriarchal structures, since they are now able to make strategic life choices and act upon those choices such as whether to spend or save their own wages which lead to transformatory significance.

\section{Decision Making Powers}

It is generally hypothesised that women's participation in economic activities leads to an improved role in decision making within the household (Unni \& Bali, 2002). In this study, interviewees were asked to reflect on whether they had noticed any changes regarding household decision making or in their attitudes and lifestyle since starting work in the factory. This study found that many of the women's decision-making powers have increased since becoming employed, but this varied in relation to types of power and marital status. However, all the women thought employment had brought about changes in their attitudes and lifestyles, making them more confident and braver.

In the absence of any male head of household, the "Independent" women were responsible for decision making. The "Independent women" said they were solely responsible for household decision making reflecting the fact that they lived independently in the city:

When I did not work, I used to listen to what my parents said. But my life has changed. I take my own decisions. Before, my parents bought clothes for me. I never went to market to buy vegetables, fish, or meat. Now I do all these things because I live here alone. When I get wages, sometimes I buy clothes for my mother and brother. When I go to visit her, I give her tk. 200 or 500, whatever I can. Besides this, I remit tk. 2,000 to her every two or three months. Before taking decisions about family matters my mother asks me for my opinion first; if I tell her not to do something, then she listens to me. (Nasima, Helper, 21, Unmarried, Non-EPZ Factory)

A convincing argument can be made in such cases that this rise in self-confidence in "Independent" women was linked with wage earning and that their status has increased within the family because they contribute to household finances. This change in status is reflected in the fact that senior family members now ask for their views when previously they would have been overlooked. This marks a significant improvement for them in terms of their status within the family, which in turn improves their bargaining power. 
Even though "Traditional" women may not have control over their income due to the unequal power relations within marriage, the RMG sector has enabled "Traditional" and "Progressive" women to exercise 'power with' with their husbands in household decision making. The most striking result in this study was that most of the women categorised as "Traditional" and "Progressive" women made joint decisions within the household ${ }^{3}$. Although "Traditional" women surrendered wages to their husbands, they were asked for their opinions regarding household expenses. All the "Progressive" women said they took household decisions jointly with their husbands, as the accounts by Sajani show:

We decide jointly how to use the money. [...] Factory work has taught me how to tackle any problem or situation within the household. So, now if my husband tells me not to go somewhere, I can convince him to let me go. (Sajani, Operator, 28, Married with children, EPZ Factory)

Interviews reveal that most "Progressive" women experienced an increasing sense of power due to the fact their earnings have given them financial independence from family members or husbands. Contributing to family subsistence gave all the "Traditional" and "Progressive" women a voice in household decision making, to a greater or lesser extent. Sajani's comment about persuading her husband to change his mind when necessary may suggest that the experience women gain in negotiating contracts and wages at the initial stages of their factory employment has helped them to develop more general skills that can be applied in their marital relationships. It is clear that, irrespective of their marital status, wage-earning women had gained a degree of decision-making power, to a greater or lesser extent. This shows that women can renegotiate preexisting patriarchal domination, since work has improved their bargaining power to exercise control in decision making, which in turn gives them the capacity to make strategic life choices over their movement.

\section{Changes in Attitudes and Lifestyles}

Women's participation in paid employment has brought changes in attitudes and lifestyle. Amin, Diamond, Naved, \& Newby (1998) argue that the technological nature of this work and their ability to operate sophisticated machines are an important part of their self-image, as is improved higher quality of life they enjoy because of migration to the city for paid employment. Evidence from this study suggests that many aspects of women's lives have improved in comparison to 
those of their rural counterparts, with increased freedom of movement and selfconfidence, autonomy, and a growing awareness of the importance of education as an agent of change is indicators of their empowerment. This change seems to result in part from their financial status within the household but is also related to the skills which they have acquired as part of the job itself.

Although "Traditional" women in this study frequently bear the double burden of productive and reproductive activities and do not control their wages, almost all interviewees spoke about changes in their attitudes and lifestyle, with all of them noting that they were more confident in their interactions with others after moving to the city. Most of these women (37 of the 40 interviewees) had migrated from rural areas of Bangladesh and confessed that initially they had experienced difficulties adjusting to city life:

When I first arrived, I felt shy talking to other people, really ill at ease. I used to think "If I speak, what will others think about me?" After three months of working, I have adjusted to this place. Now I mix with lots of people as we work in the same factory. I can find my own way around and travel back to the village alone. My friends in the village would not be able to travel independently like me. (Lovely, Operator, 22, Married with children, EPZ Factory)

Like Lovely, almost all the women reported overcoming their initial fears as one of the major changes they had experienced since starting work. Interaction with fellow factory workers helped them build their confidence and cope with a new setting. These women reported that when they first started work, they would continuously observe the behaviour of others in the factory: how other women dressed and how they interacted with each other and with men. This constant observation of co-workers' behaviour and lifestyles, as well as involvement with aspects of city life, helped them adapt to the urban lifestyle. Furthermore, the RMG sector has exposed women to new relationships outside of the kinship structure, which demonstrates an expansion of life choices, as women exercise 'power with' each other to create new relationships of solidarity through informal interactions (Souplet-Wilson, 2014).

Another aspect of change in women's lives was independent travel to the city and freedom of movement once there, showing their resistance to gender-ascribed roles of household confinement. Village women would not usually travel to distant places unaccompanied by family members, so independent travel is an important change for these women indicating a shift from private to public forms 
of patriarchy. This greater independence formed part of their lifestyle in the city. Female workers, in particular unmarried women living without parents, enjoy a degree of independence. This illustrates that factory work enables women to participate in new forms of autonomy, which in turn fosters self-confidence and increases their 'power within' themselves to believe that they are more in control of their lives than their rural counterparts. The transformatory significance is found in the fact that women are challenging patriarchal structures, as they are resisting to gender-ascribed roles of household confinement and dependence upon men.

Additionally, there is evidence that working has not only changed their attitude towards the importance of education but also helped to change the discriminatory attitudes fostered by patriarchal norms in favour of sons. In the following extracts it is noticeable that education for both boys and girls is mentioned:

I do not want my children to work in the garment factory like me. I took this work for the sake of my children's future. I want them to be educated, unlike me. My father was poor and could not afford to educate me. My elder son is studying in class IX and daughter in class III. I am working hard so they are well educated. My dream is that they will get a good job. Without education, who will give them a good job? (Nahar, Operator, 30, Married with children, NonEPZ Factory)

These accounts illustrate that although these women missed out on education themselves, they understand the value which it has and seek better opportunities for their own children or younger siblings. Many interviewees voiced regrets about not being educated enough to get better job opportunities. They are now much more aware of the importance of education and many cited this as the reason for spending money on their children's education or saving for their future, emphasising that they saw factory work as not only about changing their own lives but enabling them to transform the lives of others. Factory work has increased women's agency and made them revaluate the worth of their daughters, meaning that the traditional gender discrimination in favour of sons being educated is declining. Their own experience of factory work showed women that adult daughters, either married or single, can contribute financially to the family. The patriarchal norm of son preference is being questioned through women's investment in their daughter's education which will expand their daughter's ability to make choices for their lives in the future. 
Although the impact of the work may expand women's choices, but women still operate within the patriarchal structures of constraints, to certain extent. Some other aspects of factory work have affected women negatively, given that in Bangladesh there is still considerable social stigma attached to women working in the RMG industry. It appears that employment in the RMG industry is popularly perceived as constituting a threat to prevailing socio-cultural norms in Bangladesh, particularly by those living in rural communities. The fact that factory work allows women to interact with men on the factory floor, that factory workers live independently, unaccompanied by family members and that women have acquired bargaining power within the household are all factors which have caused female RMG workers to be popularly perceived as bad, in the sense of immoral, corrupted, or insubordinate. It can be argued that RMG factory work has disempowered women in the sense that they are marginalised within society and feel ashamed to mention their profession, particularly when looking for a potential husband or in their village community. However, there is also evidence that some women are proud of what they do, as it has ensured their own and their family's survival, a positive shift in attitudes.

\section{Conclusion}

Naila Kabeer's conceptualisation of empowerment as choice, and Walby's theory of patriarchy have allowed this paper to analyse whether RMG work has empowered women within the household and society or not. This paper has argued that experience of paid work can offer female RMG workers a degree of empowerment within home and society, but the level of this varied for different types of Bangladeshi RMG factory women, categorised here as "Traditional", "Progressive" and "Independent" women.

The process of empowerment is limited for "Traditional" women since these women's experiences are located within the private form of patriarchy in which the household constitutes an important site of oppression, with a patriarch controlling women individually and directly in the relatively private sphere of the home (Walby, 1990). "Traditional" women (who had no educational qualifications or only primary level) performed most household chores and had no control over finance. These "Traditional" women seek to uphold the status quo since they have "internalised lesser social value" in society (Kabeer, 1999, p.7). Men benefit from the domestic labour of "Traditional" women, and their 
refusal to participate and resistance to change is a demonstration of their power over women. The socialisation process has prepared "Traditional" women for their adult roles in the sexual division of labour, meaning they surrender their wages to the male head of household, whether their husband or father. These findings appear to imply that private patriarchy or the fundamental characteristics of patriarchal rule persist within the households of this "Traditional" group of female RMG factory workers. "Traditional" women's gender roles limit their ability to formulate and act on choices with a transformatory significance.

However, the process of empowerment is significant for "Independent" and "Progressive" women as there has been significant change with regards to control over their incomes, decision-making, and reproductive responsibilities. "Independent" women have more independence, they exercised control over domestic finance and household decision making and thus an increased sense of control over their lives. These interviewees were single, widowed or separated and had often been forced unwillingly into their role as breadwinner due to adverse personal circumstances, but managed to survive both within and outside the traditional male-dominated household and society. This is a process of change since previously these women were entirely dependent upon men for their living. In addition, the "Progressive" group of women was also experiencing significant changes in terms of gender relations within household. Some couples challenged tradition with the husband's involvement in household activities marking a reshaping of the traditional gender roles within the domestic sphere. These women were also unwilling to submit to male authority by simply handing over their hard-earned cash. They chose instead to retain their wages for themselves, enabling them to enjoy a degree of economic independence and a say over how this portion of their income was to be spent. This change may be linked to the fact that these women had a higher standard of education (secondary level or above) and increased material power which influenced their ability and willingness to negotiate with their husbands regarding reproductive responsibilities and financial control, which in turn increased their bargaining power within their relationships with their husbands and capacity to make life choices. For both "Independent" and "Progressive" Bangladeshi RMG factory women the scope of private patriarchy is diminishing to a significant extent because of their paid employment. 
Also, evidence from this study suggests that while purdah has served to keep women financially dependent on men throughout their lives in the domestic sphere, their role as a wage earner has reduced their dependence upon their husbands or fathers, a challenge to men's breadwinning abilities. Again, where seclusion or confinement of women within household is a norm in patriarchal family system, women's increased freedom of movement and autonomy in the urban space is another example of women's emancipation. Women highlighted the fact that this new-found independence, coupled with their social interaction with a broad range of co-workers in the factory or beyond, had contributed to the development of self-confidence and a greater degree of awareness regarding their life decisions. RMG work has given women the 'power to' make strategic life choices over their movement, the 'power with' to create new relationships outside of the kinship structure, as well as the 'power within' themselves to invest in daughter's education. This evidence indicates that RMG sector has placed women along the disempowered to empowered continuum since patriarchal norms and values (i.e., women's identity linked solely to childbearing and marriage, seclusion of women in the private sphere, culture of son preference, etc.) are being challenged.

\section{Acknowledgement}

This paper is part of the author's PhD thesis. The author would like to thank Professor Steve Vincent from Newcastle University Business School, Jean Gardiner and Kate Hardy from Leeds University Business School, UK for their supervision while pointing out that any error or imperfection in this paper is mine.

\section{Notes}

1 In Bangladesh, the first or primary level of education comprises 5 years of formal schooling (class/grades I-V). Primary education normally begins at $6+$ and lasts to 11. Secondary level is made up of 7 years of formal schooling $(3+2+2)$. The first 3 years (grades VI-VIII) is known as junior secondary; the next 2 years (grades IX-X) as secondary and last 2 years (grades XI - XII) as higher secondary.

2 Interestingly, the husbands of these RMG workers who also worked in the RMG sector earned less (tk.5, 000-6,000) than their wives (tk.7,000 or 8,000), 
because the latter were more experienced or skilled. Moreover, husbands engaged in casual work also brought home lower earnings than their wives because RMG employment provided regular income.

3 The only exception was four unmarried "Traditional" women still living with their parents who reported that their parents took household decisions.

\section{References}

Absar, S. S. (2001). Problems surrounding wages: the readymade garments sector in Bangladesh. Labour and Management in Development, 2(7), 1-17.

Ali, R. (2012). Changing Expectations of Gender Roles in Bangladesh: The Case of Female Field Staff of BRAC. Research Monograph Series, 52. (1-41) Dhaka, Bangladesh.

Amin, S., Diamond, I., Naved, R.T., \& Newby, M. (1998). Transition to Adulthood of Female Garment-factory Workers in Bangladesh. Studies in Family Planning, 29(2), 185-200.

Ansell, N., Tsoeu-Ntokoane, S., \& Hajdu, F. (2015). Women's changing domestic responsibilities in neoliberal Africa: a relational time-space analysis of Lesotho's garment industry. Gender, Place and Culture: A journal of Feminist Geography, 22(3), 363-382.

Azim, F. (2010). The new 21st century woman. In F. Azim \& M. Sultan (Eds.), Mapping women's empowerment: experience from Bangladesh, India and Pakistan (261-78). Dhaka: The University Press Limited.

Baden, S., Green, C., Goetz, A. M., \& Guhathakurta, M. (1994). Background report on gender issues in Bangladesh. Brighton, UK: Institute of Development Studies.

Batliwala, S. (2007). Taking the Power out of Empowerment: an experiential account. Development in Practice, 17(4/5), 557-565. Retrieved from: http://www.jstor.org/stable/25548253 (Accessed on October 5, 2020)

Bhopal, K. (1997). Gender, 'Race' and Patriarchy: A Study of South Asian Women. Aldershot, Brookfield USA, Singapore, Sydney: Ashgate.

Blanchet, T., \& Kramer, U. P. (1987). A Plan of Action for Assistance to Women in Bangladesh. Royal Norwegian Ministry of Development Co-operation. Bangladesh: Dhaka.

Brownmiller, S. (1976). Against our will; Men, Women, and Rape. Harmondsworth: Penguin.

Cain, M., Khanam, S. R., \& Nahar, S. (1979). Class, Patriarchy, and Women's Work in Bangladesh. Population and Development Review, 5(3), 405-438.

Chant, S., \& Brickell, K. (2013). Domesticating (and De-Patriarchalising) the Development Agenda: a need for greater household (and family) engagement in gender-related policy interventions? In: S. Rai \& G. Waylen (Eds.), New Frontiers in Feminist Political Economy (85-113). London: Routledge.

Chowdhury, F. D. (2009). Theorising Patriarchy: The Bangladesh Context. Asian Journal of Social Science, 37(4), 599-622.

Delphy, C. (1984). Close to Home: A Materialistic Analysis of Women's Oppression. Amherst, MA: University of Massachusetts Press.

Eisenhardt, K. M. (1989). Building Theories from Case Study Research. The Academy of Management Review, 14(4), 532-550. 
Elson, D. (2014). Economic Crisis from the 1980s to the 2010s: A gender analysis. In: S. Rai \& G. Waylen (Ed.), New Frontiers in Feminist Political Economy (189-212). London: Routledge.

Feldman, S. (1992). Crisis, Islam and gender in Bangladesh: The social construction of a female labour force. In L. Beneria \& S. Feldman (Eds.), Unequal burden: Economic cries, persistent poverty, and women's work (105-130). Boulder, Co: Westview.

Feldman, S. (2001). Exploring Theories of Patriarchy: a perspective from Contemporary Bangladesh. Signs, 26(4), 1097-1127. Retrieved from: http://www.jstor.org/stable/3175358

Fernandez-Kelly, M. P. (1990). Delicate transactions: Gender, home, and employment among Hispanic women. In F. Ginsburg \& A. L. Tsing (Eds.), Uncertain terms: Negotiating gender in American Culture (183-195). Boston: Beacon.

Glick, P., \& Roubaud, F. (2006). Export Processing Zone Expansion in Madagascar: What are the Labour Market and Gender Impacts? Journal of African Economies, 15(4), 722-756.

Goetz, A. M. (1999). Managing organisational change: the 'gendered' organization of space and time. In C. Sweetman (Ed.), Gender in Development Organisations 5(1), 17-27.

Hancock, P. (2006). Women, Work and Empowerment: A portrait of women workers in two of Sri Lanka's export processing zones. Norsk Geografisk Tidsskrift-norwegian Journal of Geography, 60(3), 227-239.

Hartmann, H. (1979). The Unhappy Marriage of Marxism and Feminism: Towards a More Progressive Union. Capital and Class, 3(1), 1-33.

Hossain, N. (2012). Women's empowerment revisited: From individual to collective power among the export sector workers of Bangladesh. IDS Working Papers, (389), 1-40.

Hussain, S. (2011). Challenges of Globalization: How Bangladesh can adapt itself to reap the best benefits in the 21st Century. MIST International Journal of Science and Technology, 3(1), 1-10.

Kabeer, N. (1997). Women, Wages and Intra-household Power Relations in Urban Bangladesh. Development and Change, 28(7), 261-302.

Kabeer, N. (1999). The Conditions and Consequences of Choice: Reflections on the measurement of Women's Empowerment. (Vol. 108, pp. 1-58) Geneva: UNRISD.

Kabeer, N. (2004). Globalization, Labour Standards, and Women's Rights: Dilemmas of Collective (In) Action in an Interdependent World. Feminist Economics, 10(1), 3-35.

Kabeer, N. (2010). Gender Equality and Women's Empowerment: A critical analysis of the third millennium development goal 1. Gender and Development, 13(1), 13-24. Retrieved from: http://dx.doi.org/10.1080/13552070512331332273 (Accessed on October 8, 2020)

Kabeer, N. (2014). The Rise of the Female Breadwinner: Reconfigurations of marriage, motherhood and masculinity in the global economy. In: S. Rai, and G. Waylen (Ed.), New Frontiers in Feminist Political Economy (62-84). London: Routledge.

Kabeer, N. and Mahmud, S. (2004a). Rags, Riches and women workers: Export-oriented Garment Manufacturing in Bangladesh. In Commonwealth Secretariat (Ed.), Chains of Fortune: Linking women producers and workers with global markets (133-162). London: Commonwealth Secretariat.

Kabeer, N., \& Mahmud, S. (2004b). Globalization, Gender and Poverty: Bangladeshi Women Workers in Export and Local Markets. Journal of International Development, 16(1), 93-109.

Kibria, N. (1995). Culture, social class, and income control in the lives of women garment workers in Bangladesh. Gender and Society, 9(3), 289-309. 
Khosla, N. (2009). The ready-made garments industry in Bangladesh: A means to reducing genderbased social exclusion of women? Journal of International Women's Studies, 11(1), 289-303.

Kramsjo, B., \& Wood, G. (1992). Breaking the Chains: Collective Action for Social Justice among the Rural Poor in Bangladesh. London: Intermediate Technology Publications.

LeGates, M. (2001). In their Time: A History of Feminism in Western Society. New York and London: Routledge.

MacKinnon, C. (1989). Towards a Feminist Theory of the State. Cambridge, Mass.: Harvard University Press.

Malhotra, A., Schuler, S. R., \& Boender, C. (2002). Measuring women's empowerment as a variable in international development. In background paper prepared for the World Bank Workshop on Poverty and Gender: New Perspectives (Vol. 28).

Meyer, L. B. (2006). Trade Liberalization and Women's Integration into National Labour Markets: A Cross-Country Analysis. Social Indicators Research, 75(1), 83-121.

Millett, K. (1970). Sexual Politics. New York: Doubleday.

Oakley, P. (2001). Evaluating Empowerment: Reviewing the Concept and Practice. Oxford: INTRAC.

Ong, A. (1987). Spirits of Resistance and Capitalist Discipline: Factory Women in Malaysia. State University of New York Press: Albany, NY.

Paul-Majumder, P., \& Begum, A. (2000). The gender imbalances in the export-oriented garment industry in Bangladesh. Policy Research Report on Gender and Development. Washington, DC: World Bank, Development Research Group/Poverty Reduction and Economic Management Network.

Pearson, R. (2004). Women, Work and Empowerment in a Global Era. IDS Bulletin, 35(4), 117-120.

Pearson, R. (2007). Beyond Women Workers: Gendering CSR. Third World Quarterly, 28(4), 731-749.

Rao, N. (2012). Breadwinners and Homemakers: Migration and Changing Conjugal Expectations in Rural Bangladesh. Journal of Development Studies, 48(1), 26-40.

Rich, A. (1980). Compulsory Heterosexuality and Lesbian existence. Signs, 5(4), 631-660.

Rowlands, J. (1997). Questioning Empowerment: Working with Women in Honduras. Oxford: Oxford Publications.

Safa, H. I. (1990). Women and Industrialization in the Caribbean. In S. Sticher, \& J. Parpart (Eds.), Women, Employment and the Family in the International Division of Labour (72-97). Basingstoke: Macmillan.

Said-Allsopp, M. (2013). Empowerment within global value chains: A Study of the Dynamics of Employment and its Impacts on the Lives of Women Employed Kenyan Agricultural Export Industries. (Doctoral dissertation). UK: University of Leeds. (School of Earth and Environment)

Sen, G., \& Grown, C. (1987). Development, Crises and Alternative Visions: Third World Women's Perspectives. London: Earthscan Publications Ltd.

Souplet-Wilson, S. (2014). Made in Bangladesh: A critical analysis of the empowerment dynamics related to female workers in the Bangladeshi Ready-Made-Garment sector. Journal of Politics and International Studies, 11, 359-397.

Sultana, A. M. (2010). Socio-cultural dimensions of women's discriminations in rural communities. Ozean Journal of Social Sciences, 3(1), 31-38. 
Zapata, E., \& Townsend, J. (1999). Outsiders and self-empowerment. Women and power: Fighting patriarchies and poverty. J. Townsend, E. Zapata, J. Rowlands, P. Alberti and M. Mercado. London, Zed Books.

Tracy, S. J. (2013). Qualitative Research Methods: Collecting Evidence, Crafting Analysis, Communicating Impact. Hoboken, NJ: Wiley-Blackwell.

Unni, J., \& Bali, N. (2002). Subcontracted Women Workers in the Garment Industry in India. In R. Balakrishnan (Ed.), The Hidden Assembly Line: Gender Dynamics of Subcontracted Work in a Global Economy (115-144). Bloomfield: Kumarian Press.

Walby, S. (1989). Theorising Patriarchy. Sociology, 23(2), 213-234.

Walby, S. (1990). Theorizing Patriarchy. Oxford: Basil Blackwell.

Walby, S. (1996a). Key concepts in Feminist Theory. (Paper no. 33, 1-18). Aalborg University: Department of Development and Planning.

Walby, S. (1996b). The 'Declining Significance' or the 'Changing Forms' of Patriarchy? In V. M. Moghadam (Ed.), Patriarchy and Economic Development: Women's Positions at the End of the Twentieth Century (19-33). Oxford: Clarendon Press.

Ward, K., Rahman, F., Islam, S. A. K. M., Akhter, R., \& Kamal, N. (2004). The effects of global economic restructuring on urban women's work and income-generating strategies in Dhaka, Bangladesh, Critical Sociology, 30(1), 63-102.

Weber, M. (1947). The Theory of Social and Economic organisation. New York: Free Press.

Wilson-Smillie, D., Eggen, C., \& Shefali, M. (1990). Gender Strategy for CIDA in Bangladesh. Ontario, Canada: CIDA.

World Bank. (2012). World Development Report: Gender Equality and Development. Washington: The World Bank.

Wright, M. W. (2006). Disposable women and other myths of global capitalism. New York and London: Routledge.

Zaman, H. (2001). Paid work and socio-political consciousness of garment workers in Bangladesh. Journal of Contemporary Asia, 31(2), 145-160. 